\title{
LATAR BELAKANG DAN DAMPAK PERCERAIAN (STUDI KASUS DI PENGADILAN AGAMA KELAS 1 A PALEMBANG)
}

\author{
Mukmin, S.H.I., M.Sy. \\ Balai Diklat Keagamaan Palembang, Kementerian Agama, Palembang \\ mukminmukri@gmail.com
}

\author{
Diterima: 23 Maret | Disetujui: 17 April| Dipublikasikan: 23 April
}

\begin{abstract}
ABSTRAK
Membentuk keluarga yang kekal, bahagia dan sejahtera merupakan tujuan pokok dalam rumah tangga. Tujuan suci tersebut sering kandas di tengah jalan, karena pasangan tidak dapat mempertahankan hubungan keluarga secara harmonis dan berakhir dengan perceraian. Tujuan penelitian ini adalah mengetahui latar belakang dan dampak perceraian di Palembang. Metodologi penelitian yang digunakan adalah kualitatif deskriptif dengan teknik pengumpulan data menggunakan observasi, wawancara dan dokumentasi. Teknik keabsahan data menggunakan triangulasi data. Hasil penelitian menunjukkan bahwa perceraian disebabkan karena beberapa faktor, antara lain: faktor moral meliputi poligami tidak sehat, krisis akhlak, cemburu, Faktor meninggalkan kewajiban meliputi kawin paksa, ekonomi, tidak ada tanggung jawab, Faktor kawin di bawah umur, Faktor penganiayaan, faktor perselisihan meliputi gangguan pihak ketiga, dan keharmonisan. Saran yang dapat peneliti berikan adalah bagi orang tua tidak menikahkan anaknya dengan cara paksa, yaitu menikahkan anaknya dengan orang yang tidak dicintainya. Karena perkawinan harus ada kesepakatan antara kedua calon mempelai, Bagi pasangan suami-isteri hendaknya saling memahami, saling terbuka dalam rumah tangga untuk memecahkan masalah yang dihadapi, sehingga tidak terjadi disharmonis dalam keluarga. Langkah yang ditempuh adalah dengan cara mengemukakan permasalahan yang ada, kemudian permasalahan tersebut dibicarakan bersama dan dicari jalan keluarnya bersama-sama, salah satunya adalah harus ada yang mengalah dan saling menyadari satu sama lain, sehingga perselisihan cepat terselesaikan dengan damai, Bagi masyarakat hendaknya dilakukan penyuluhan hukum perceraian dengan segala aspeknya, guna merangsang kokohnya ikatan perkawinan dan mengurangi angka perceraian.
\end{abstract}

Kata kunci: dampak perceraian, moral, peradilan 


\begin{abstract}
[LATAR BELAKANG DAN DAMPAK PERCERAIAN (STUDI KASUS DI PENGADILAN AGAMA KELAS 1A PALEMBANG)].Forming a family that is eternal, happy and prosperous is the main goal in the home. To achieve a happy and prosperous household requires cooperation and mutual understanding between husband and wife, and avoiding all kinds of disputes in the household. These sacred goals often run aground along the way, because the couple cannot maintain family relationships harmoniously and ends in divorce. The purpose of this study was to determine the background and impact of divorce in Palembang. The research methodology used is descriptive qualitative with data collection techniques using observation, interviews and documentation. The data validity technique used data triangulation. The results showed that divorce was caused due to several factors, including: moral factors including unhealthy polygamy, moral crisis, jealousy, factors leaving obligations including forced marriage, economy, no responsibility, underage factors, persecution factors, disputes factors includes third party interference, and harmony. The suggestion that the researcher can give is for parents not to marry their children by force, namely marrying off their children to people they do not love. Because marriage there must be an agreement between the two prospective brides, husband and wife should understand each other, be open to each other in the household to solve the problems faced, so that disharmony occurs in the family. The step taken is by putting forward the existing problems, then the problems are discussed together and a solution is sought together, one of which is that there must be someone who gives in and is aware of each other, so that disputes are resolved quickly peacefully. For the community, counseling should be carried out. divorce law in all its aspects, in order to stimulate the strengthening of the marriage bond and reduce the divorce rate.
\end{abstract}

Keyword : Impact of Divorce, Moral, Court

This work is licensed under a Creative Commons Attribution-NonCommercial 4.0 


\section{PENDAHULUAN}

Hasrat yang dimiliki oleh setiap insan inilah yang mendukung masing-masing individu untuk mencari pasangan hidupnya yaitu dengan membentuk suatu keluarga. Keluarga adalah sebuah kelompok manusia terkecil yang didasarkan atas ikatan pernikahan, sehingga membentuklah sebuah rumah tangga. Untuk dapat melangsungkan suatu pernikahan harus memenuhi syarat sahnya pernikahan. Dengan demikian pernikahan yang sah, apabila dilakukan menurut hukum agama dan kepercayaannya masing-masing (pasal 2 ayat 1 UU No.1 tahun 1974).

Manusia merupakan makhluk sosial, sebagai keinginan "sang pencipta" yang telah memberikan perlengkapan " rukun " sehingga kenyataan ini diungkapkan oleh Aristoteles yang pada 300 (tiga ratus tahun) Sebelum Masehi bahwa manusia adalah suatu "zoon politikon", ungkapan ini biasa diartikan sebagai “ manusia merupakan makhluk sosial", yang berarti manusia itu memiliki sifat untuk mencari kumpulannya dengan sesama manusia yaitu dengan suatu pergaulan. (Ari Wilianto: Kompas, 2021)

Permasalahan yang akan penulis angkat dalam tulisan ini adalah apa yang menjadi faktor terjadinya perceraian dan bagaimana dampak perceraian terhadap para pihak

Perkawinan merupakan perjanjian yang setia, dan sama-sama bertanggung jawab dalam menunaikan tugasnya sebagai suami-isteri atas keselamatan dan kebahagiaan keluarga. Perjanjian tersebut harus sama dengan syarat sahnya perjanjian yaitu pasal 1320 KUHPerdata adalah:

\section{Kesepakatan}

Mempunyai rasa ikhlas atau saling memberi dan menerima atau sukarela diantara pihak yang membuat perjanjian tersebut. Kesepakatan tidak dapat disahkan apabila dibuat atas dasar paksaan, penipuan, atau kekhilafan.

\section{Kecakapan}

Para pihak yang membuat perjanjian harus orang-orang yang oleh hukum dinyatakan sebagai subyek hukum yaitu yang cakap hukum. Tidak cakap ialah orang-orang yang ditentukan hukum, yaitu anak-anak, orang dewasa yang ditempatkan dalam pengawasan (curatele), dan orang sakit jiwa. Mereka yang belum dewasa menurut UUP adalah anakanak karena belum berumur 18 (delapan belas) tahun. Meskipun belum berumur 18 (delapan belas) tahun, apabila seseorang telah atau pernah menikah dianggap sudah dewasa, berarti cakap untuk membuat perjanjian.

3. Hal tertentu

Objek yang diatur dalam perjanjian ini harus jelas. Hal ini penting untuk memberikan jaminan kepada pihak-pihak tertentu dan mencegah timbulnya fiktif, misal: orang jelas, anak siapa.

4. Sebab yang dibolehkan

Isi dalam perjanjian tidak boleh bertentangan dengan perundang-undangan yang bersifat memaksa, ketertiban umum, atau kesusilaan. Misal: adanya paksaan dalam menikah.

Pernikahan adalah perjanjian untuk dua orang yaitu antara seorang laki-laki dan seorang perempuan dengan tujuan material, yakni membentuk keluarga yang bahagia, dan abadi berdasarkan Ketuhanan Yang Maha Esa (Soedaryono Soimin, 1992: 6)

Dalam suatu pernikahan semua orang menginginkan kehidupan rumah tangga yang bahagia, abadi, dan sejahtera, sesuai dengan tujuan dari pernikahan yang tertera dalam Undang-Undang No.1 tahun 1974 Juncto UU No 16 tahun 2019 tentang perubahan Undang-Undang Perkawinan. Akan tetapi, tidak semua manusia dapat membentuk suatu keluarga yang dicitacitakan tersebut, hal ini dikarenakan adanya perpisahanan, baik berpisah mati, berpisah talaq, maupun berpisah atas putusan hakim. 
Perceraian ialah putusnya ikatan pernikahan antara seorang laki-laki dengan seorang perempuan sebagai suami dan isteri, yang dilakukan di depan sidang Pengadilan, yaitu Pengadilan Negeri untuk yang beragama non muslim dan Pengadilan Agama bagi yang muslim. Sedangkan arti perceraian menurut hukum perdata adalah penghapusan pernikahan dengan putusan hakim atas tuntutan salah satu pihak dalam pernikahan itu. Untuk melakukan perceraian harus cukup alasannya, sebagaimana yang tertera dalam pasal 39 UU No.1 tahun 1974 Juncto UU No 16 tahun 2019 tentang perubahan Undang-Undang Perkawinan dan pasal 19 PP No.9 tahun 1975. Pasal 39 menyebutkan : (Erizka Permatasari: Klinik Hukum Online, 2021)

1. Perceraian hanya bisa dilakukan di depan sidang Pengadilan setelah Pengadilan yang bersangkutan berusaha dan tidak berhasil mendamaikan kedua belah pihak.

2. Untuk melakukan perceraian harus cukup alasan, bahwa antara suami dan isteri itu tidak akan dapat hidup rukun sebagai suami dan isteri.

3.Tata cara perceraian di sidang Pengadilan telah diatur dalam Peraturan Perundang-undangan tersendiri.

Sedangkan dalam pasal 19 PP No. 9 tahun 1975 menerangkan:

1. Salah satu pihak berbuat zina atau menjadi pemabok dan lain sebagainya yang sulit disadarkankan.

2. Salah satu pihak meninggalkan pihak lain selama 2 (dua) tahun berturutturut tanpa izin dari pihak lainnya dan tanpa alasan yang sah atau karena hal lain diluar kemampuannya.

3. Salah satu pihak mendapat hukuman kurungan selama 5 (lima) tahun atau lebih dengan hukuman berat setelah pernikahan berlangsung.

4. Salah satu pihak melakukan tindakan kekerasan atau tindakan penganiayaan yang membahayakan pihak lain.

5. Salah satu pihak cacat badan atau mengidap penyakit yang mengakibatkan tidak dapat menjalankan kewajibannya sebagai suami-isteri.

6. Antara suami dan isteri terus menerus terjadi perselisihan dan pertengkaran serta tidak ada harapan akan hidup rukun dalam berrumah tangga.

\section{METODE PENELITIAN}

Metode penelitian Metode penelitian yang dilakukan dalam penelitian ini adalah penelitian kualitatif. Sumber data. Sumber data yaitu subyek dimana data ini diperoleh. Sumber data dalam penelitian ini penulis hanya mengambil sebagian responden (sebagian orang) yang dapat mewakili untuk keseluruhan. Penelitian kualitatif adalah katakata dan tindakan selebihnya dokumen dan lain-lain. Teknik pengumpulan data yang dilakukan adalah dengan menggunakan wawancara, observasi dan dokumentasi. Teknik Keabsahan data menggunakan Triangulasi Data (Arikunto Suharsimi, 1996: 114).

\section{Temuan Dan Pembahasan}

\section{Temuan}

Dari hasil penelitian dan berdasarkan data dari Kantor Pengadilan Agama kelas $1 \mathrm{~A}$ Palembang bahwa tingginya tingkat perceraian disebabkan karena beberapa faktor diantaranya:

\section{a. Moral}

Moral ialah tingkah laku, percakapan, perbuatan bahkan sesuatu apapun yang bersangkutan dengan norma-norma kesopanan, yang harus atau dilindungi oleh hukum demi terciptanya tata tertib dan tata cara dalam kehidupan bermasyarakat. Ada beberapa hal yang menjadi temuan penulis disini dalam ranah moral seperti poligami, krisis akhlak, cemburu kepada pasangan. 


\section{b. Meninggalkan kewajiban}

Kewajiban adalah kewajiban yang ditinggalkan oleh suami atau isteri yang berupa nafkah baik lahir maupun batin. Mereka meninggalkan kewajiban sebagai suami-isteri karena adanya beberapa hal diantaranya adalah kawin paksa, ekonomi, tidak ada tanggung jawab.

a. Kawin paksa

Kawin paksa merupakan faktor penyebab perceraian karena kawin paksa tidak dilandasi rasa cinta, kasih dan sayang. Kawin paksa terjadi karena adanya paksaan dari orang tua, saudara atau yang lainnya yang menyebabkan perasaan dipaksa.Sedangkan untuk melangsungkan suatu perkawinan harus ada rasa suka sama suka, atau kesepakatan bersama dan tidak ada paksaan dari siapapun. Oleh karena kawin paksa itu adalah yang menjadi korban hatinya, karena salah satu tidak mencintai atau kedua-duanya tidak mencintai. Cinta tidak dapat terjadi dalam sekali pandang, karena cinta membutuhkan proses yaitu melalui pertemuan, perkenalan, dan lebih jauh lagi, sehingga timbullah cinta. Dengan tidak adanya saling cinta otomatis sebagai wanita tidak mau berhubungan seksual dan bahkan sampai tidak mau mengurus rumah tangga. Bagi laki-laki karena tidak mencintai, maka tidak mau memberi nafkah lahir maupun batin (nafkah wajib). Sedangkan hak isteri adalah menuntut nafkah bagi suaminya dan sebaliknya kewajiban suami adalah memberikan nafkah baik lahir maupun batin bagi isterinya.

b. Ekonomi

Ekonomi adalah kurang tercukupinya kebutuhan ekonomi atau adanya keinginan yang berlebihan, sedangkan pendapatan tidak sesuai dengan pengeluaran. Hal ini dapat mengakibatkan pertengkaran terus dan dapat berakhir dengan perceraian. Jadi, antara kenyataan dengan teori sama yaitu faktor penyebab perselisihan yang mengakibatkan perceraian adalah faktor ekonomi atau keuangan. Sebagai seorang suami harus bertanggung jawab terhadap keluarganya termasuk dalam memberikan nafkah lahir kepada isteriya. Adanya keterbukaan diantara suami isteri dalam membelanjakan atau penggunaan uang merupakan kunci utama dalam berumah tangga. Seorang isteri hendaklah dapat membelanjakan uang secara cermat, jangan menggunakan uang untuk keperluan yang kurang bermanfaat.

b. Tidak ada tanggung jawab.

Perceraian dapat terjadi karena tidak adanya tanggung jawab dari keduanya yaitu baik nafkah lahir maupun batin dan karena meninggalkan rumah disengaja maupun tidak tanpa izin dari isteri atau suami. Dalam suatu pernikahan wajib memberi nafkah baik lahir maupun batin. Apabila salah satu tidak terpenuhi maka akan berdampak tidak harmonis terhadap rumah tangga tersebut. Dalam hal ini pasangan suami-istri harus sama-sama dapat saling memuaskan atau saling memberi dan saling menerima satu sama lain. Dalam suatu pernikahan atau rumah tangga harus ada rasa tanggung jawab antara keduanya, sehingga terjalinlah keluarga yang harmonis.

c. Menikah dibawah umur

Menikah di bawah umur adalah pernikahan yang dilangsungkan karena belum cukup umur. Pernikahan ini banyak yang mengalami tidak sukses, dikarenakan mereka belum sepenuhnya memahami arti dan tujuan dari pernikahan tersebut. Sehingga apabila dalam rumah tangga terjadi kegoncangan, mereka tidak dapat mengatasinya atau mencari solusinya. Mereka hanya dapat menyalahkan satu sama lain. Secara teori, bagi seorang yang belum mencapai umur 21 tahun, untuk melangsungkan pernikahan harus mendapat izin dari kedua orang tua. Menurut ketentuan pasal $7 \mathrm{UU}$, 
perkawinan hanya diizinkan jika pihak pria telah mencapai umur 19 (sembilan belas) tahun dan pihak wanita telah mencapai umur 16 tahun. Batas ini ditetapkan bermaksud untuk menjaga kesehatan suami-isteri, dan keturunannya, yang berarti bahwa seorang yang belum mencapai umur 21 (dua puluh satu) tahun harus mendapat izin kedua orang tua, dikarenakan mereka dianggap belum dewasa. Sedangkan pernikahan ialah ikatan lahir batin antara pasangan laki-laki dengan seorang perempuan sebagai suami-istri dengan tujuan membentuk keluarga (rumah tangga) yang bahagia dan abadi berdasarkan Ketuhanan Yang Maha Esa (pasal 6 jo pasal 7 UndangUndang No.1 tahun 1974 Juncto UU No 16 tahun 2019 tentang perubahan Undang-Undang Perkawinan).

\section{d. Penganiayaan}

Penganiayaan yang dimaksud disini adalah melakukan kekejaman baik jasmani dan atau rohani. Kekejaman terhadap jasmani dapat dilihat dari perbuatan yang dapat menimbulkan sakit atau yang termasuk tindakan pidana. Sedangkan kekerasan rohani seperti hinaan, fitnah atau hal lain yang mengganggu kejiwaan Mengenai penganiayaan berat ini termasuk melukai berat atau penganiayaan yang membahayakan jiwanya dan tindakan itu suatu tindakan yang dilakukan oleh suami atau isteri terhadap isteri atau suami. Apabila salah satu pihak dianiaya misalnya dipukul, disiram jarang, dijambak, hal ini termasuk penganiayaan. Secara teori apabila salah satu pihak terdapat melakukan kekerasan atau penganiayaan berat yang membahayakan pihak lain maka ia berhak mengajukan gugatan cerai (pasal 19 sub d PP No. 9 tahun 1975 ). Jadi, kenyataan dengan teori sama. Untuk menjalankan rumah tangga yang baik harus ada saling pengertian atau menghargai, saling memberi dan menerima, sehingga tidak timbul fitnah yang menyebabkan terjadinya kekerasan. Karena orang yang melakukan penganiayaan baik terhadap suami maupun isteri dapat membahayakan jiwa seseorang dan terancam dengan hukuman. Penganiayaan selain dapat dijadikan alasan bercerai juga apabila penganiayaan itu sudah terlalu berat dapat dilaporkan ke pihak yang berwenang (terkena hukum pidana), karena manusia dilindungi oleh hukum. Untuk itu diharapkan para pasangan suami-isteri, dapat menyelesaikan suatu kasus atau perselisihan dalam rumah tangga dengan sebaik-baiknya, dengan kepala dingin, jangan menggunakan amarah atau kekuatan atau dengan jalan kekeluargaan, sehingga upaya damai dapat terwujud.

e. Terus menerus berselisih

Perceraian terjadi karena adanya cekcok yang terus menerus, sehingga dengan upaya apapun tidak dapat didamaikan.

a. Gangguan pihak ketiga

Adanya campur tangan atau gangguan pihak ketiga yaitu orang tua, saudara dari suami/isteri, teman dalam rumah tangga yang dapat menyebabkan perbedaan prinsip maupun pendapat/ salah paham diantara mereka, sehingga terjadi perselisihan yang hebat dan berakhir dengan perceraian. Apabila sifat pihak ketiga itu baik tentu tidak akan jadi masalah, tetapi bagaimana jika pihak ketiga itu jahat. Pihak ketiga yang dimaksud yaitu orang tua, saudara dari suami/ istri yang ada hubungan keluarga dengannya, orang lain yaitu selingkuhannya wanita/ pria.

Hal inilah yang kerap kali mengganggu jalannya rumah tangga yang tadinya harmonis menjadi berantakan. Apabila orang tua turut campur urusan rumah tangga anaknya yaitu orang tua beranggapan bahwa ia akan melakukan 
apa yang terbaik buat anaknya, tetapi sebaliknya apa yang terbaik menurut orang tua belum tentu baik menurut anaknya. Adanya pengaruh orang tua yang tidak baik/ tidak sependapat dengan anaknya, baik terhadap anaknya sendiri/ menantunya, tetap dapat mengakibatkan retaknya rumah tangga. Hal ini disebabkan karena terjadinya salah paham diantara keduanya dan terjadi pertengkaran/ cekcok yang tiada hentinya.

Orang tua kadang tidak memahami bahwa hal itu merusak rumah tangga anaknya sendiri. Anak terkadang mengikuti apa kehendak orang tuanya walaupun merugikan dirinya. Hal inilah yang membuat rumah tangga berantakan dan berakhir dengan perceraian. Terkadang saudara dari suami/ isteri juga ikut campur dalam rumah tangga. Biasanya dalam hal pengaturan keuangan, ia mempengaruhi saudaranya untuk memberikan nafkah sedikit, dan sisanya untuk orang tua/adik-adiknya. Hal lain saudara dari suami/istri meminta uang kakaknya terus sehingga rumah tangga menjadi ribut/saudara-saudaranya main kerumah kakaknya terus menerus setiap hari dan dibarengi dengan penyebaran fitnah yang tidak baik, yang mengakibatkan pihak suami/istri sudah tidak saling percaya lagi, dan hanya percaya pada masing-masing saudaranya. Sehingga terjadilah pertengkaran yang hebat dan tidak bisa didamaikan yang berakhir di Pengadilan dengan perceraian. Selain itu juga dengan adanya pria idaman lain/wanita idaman lain. Misalnya suami bekerja di kantor dan mempunyai sekretaris dan sekretaris tersebut perhatiannya lebih dibanding suaminya. Suami dapat tertarik dengan wanita lain karena istri kurang dapat memahami apa yang diinginkan suaminya atau sebaliknya. Adanya wanita lain/ pria lain (pihak ketiga) yang dapat mengakibatkan perselingkuhan. Jadi, dengan adanya gangguan pihak ketiga inilah yang dapat mengakibatkan perselisihan/ cekcok terus menerus dan akibat salah paham yang dilakukan oleh pihak ketiga, inilah yang dapat memicu terjadinya perceraian.

Secara teori, peceraian dapat terjadi karena antara suami dan isteri terusmenerus terjadi perselisihan dan pertengkaran dan tidak ada harapan untuk hidup rukun lagi (pasal 19 sub $f$ PP Nomor. 9 tahun 1974 dan pasal 39 UUP). Jadi, apabila kenyataan dengan teori sama. Untuk menjalankan rumah tangga yang harmonis harus ada saling percaya diantara suami-isteri. Apabila ada gangguan dari pihak manapun,baik dari pihak laki-laki atau pihak wanita dan lainnya, sebaiknya diselidiki terlebih dahulu. Jangan mudah percaya dengan orang lain sebelum dapat membuktikannya sendiri. Bagaimanapun istri merupakan selimut bagi suami dan sebaliknya suami merupakan selimut bagi istrinya. Jadi, mereka harus dapat melindungi dan mempertahankan keutuhan rumah tangganya sendiri dari gangguan siapapun dengan cara saling percaya diantara mereka.

b. Tidak adanya keharmonisan Apabila dalam suatu rumah tangga terjadi perselisihan atau cekcok yang terus menerus, dan upaya damai tidak dapat tercapai. Untuk menentukan ada atau tidak adanya cekcok maka salah satu pihak (suami/ isteri) harus dapat membuktikan kepada Pengadilan tentang hal yang menyebabkan cekcok dalam rumah tangga tersebut. Cekcok itu harus ada secara nyata dengan cara mendengarkan keterangan dari pihak yang menuntut perceraian dan jika mungkin juga dari pihak yang lain (suami/ isteri) yang diajukan anggota keluarga serta kawan-kawan sepergaulan suami/ isteri atau selain dari suami atau isteri juga keterangan dari saksi.

Rumah tangga yang tidak harmonis 
ialah rumah tangga yang diliputi berbagai konflik, yang tidak dapat dipecahkan atau tidak ada jalan keluarnya kecuali dengan perceraian. Al-Qur' an al karim sebagaimana sumber pokok tidak memberikan pedoman bahwa kaum pria atau suami menjadi "qowwamun" atas kaum wanita yang menjadi istrinya. Kandungan "qowwamun" inilah yang menjadi sifat responsiv dalam membina keluarga yang bahagia. Kehidupan rumah tangga yang baik menjadi wajib hukumnya menurut syari' at islam

\section{PEMBAHASAN}

\section{Dampak Perceraian}

Dari hasil penelitian yang penulis lakukan melalui wawancara / pengamatan, dampak perceraian yang dilakukan oleh pasangan suami-istri, baik yang sudah mempunyai anak maupun yang belum di wilayah pengadilan agama Palembang sebagai berikut, ada tiga dampak yang dapat penulis paparkan :

\section{A. Dampak terhadap suami/ istri}

Perceraian meskipun merupakan masalah yang sudah biasa terjadi di lingkungan rumah tangga, tetapi akibatnya sangat menakutkan jika diperhatikan dengan betul-betul. Bagi mantan suami-istri dengan perceraian sudah kehilangan kemurniannya sebagai jejaka menjadi duda dan gadis berganti memperoleh status sebagai janda. Lebihlebih lagi bagi bekas istri, panggilan janda dapat memberikan kesan yang kurang enak didengar oleh telinga, dapat menimbulkan rasa kekhawatiran, raguragu, ada juga yang sampai membenci laki-laki, sehingga ia tidak mempercayai laki-laki lagi.

Sedangkan bagi bekas suami dapat bersikap masa bodoh dengan status yang di sandangnya setelah perceraian, mencari pasangan yang tidak sah. Selain itu juga mencari kepuasan sesaat/iseng dapat juga bekas suami menjadi orang yang patah semangat dalam segala hal.

Apabila ada seorang janda cantik yang bersilaturahmi ke rumah tetangga, dan tetangganya itu ada seorang pria baik duda maupun sudah berkeluarga/jejaka. Maka masyarakat akan beranggapan bahwa wanita itu perusak rumah tangga orang atau wanita itu dicaci maki dengan perkataan jelek, suka ganggu suami orang (Pelakor) dan yang lainnya (masyarakat setempat). Kejadian inilah yang dapat mengganggu ketentraman hati seorang janda tersebut, sehingga dapat berakibat janda itu frustasi dan akhirnya melakukan hal yang tidak baik. Misalnya minumminuman dan bahkan bisa sampai melakukan percobaan bunuh diri. Bagi seorang pria sedikit berbeda dengan wanita.

Walaupun dia berstatus duda dia tetap tabah menghadapi cobaanya. Karena seperti pepatah bilang "Tua-tua keladi" yang artinya makin tua makin menjadi, "banyak santan banyak garam " artinya orang yang semakin banyak pengalamannya dalam berumah tangga ia akan semakin dewasa dan memahami arti dari pernikahan dan baik untuk menjalankan rumah tangga selanjutnya. Selain itu ada pendapat yang tidak baik juga yaitu "laki-laki buaya" artinya lakilaki itu suka mempermainkan wanita, walaupun dengan istrinya sendiri apalagi dengan wanita lain.

Setelah pernikahan putus karena perceraian, maka suami-istri di perbolehkan menikah lagi, dengan ketentuan bagi bekas istri harus memperhatikan waktu tunggu.

Secara teori, akibat perceraian ini diatur dalam pasal 41 UU No. 1 tahun 1974 Juncto UU No 16 tahun 2019 tentang perubahan Undang-Undang Perkawinan yaitu:

a. Ibu atau bapak tetap berkewajiban memelihara dan mendidik anak- 
anaknya, semata-mata berdasarkan kepentingan pertumbuhan dan pendidikan anak. Apabila terdapat perselisihan mengenai pengasuhan anak, maka Pengadilan yang memberi keputusan.

b. Bapak yang bertanggung jawab atas semua biaya perawatan dan pendidikan yang diperlukan anak tersebut, apabila bapak dalam kenyataan tidak memenuhi kewajiban tersebut, maka Pengadilan dapat menentukan bahwa ibu ikut memikul biayanya.

c. Pengadilan bisa mewajibkan kepada mantan suami untuk memberikan biaya kehidupan, dan atau menentukan sesuatu kewajiban.

Dari uraian tersebut diatas, dapat ditarik kesimpulan bahwa kenyataan dengan teori berbeda yaitu dalam kenyataan dampak perceraian terhadap suami maupun isteri adalah bersifat individual, mementingkan diri sendiri tidak mau taat pada aturan yang ditetapkan baik oleh UUP, KUHPerdata maupun oleh Hukum Islam yang dikenakan. Sedangkan dalam teori begitu ketatnya aturan yang harus dijalankan bagi bekas suami dan bekas isteri.

Perceraian adalah merupakan hal yang sangat dibenci Tuhan walaupun hal itu halal dan merupakan jalan terakhir apabila upaya damai sudah tidak bisa lagi dilakukan. Perceraian sangat merugikan baik bagi pihak suami maupun pihak isteri. Untuk itu diharapkan apabila terdapat suatu perselisihan diantara keduanya diselesaikan dengan baik-baik melalui jalan kekeluargaan, dengan cara saling menghargai pendapat satu sama lain. Adanya kompromi, saling pengertian, saling menghargai, atau menghormati dan melaksanakan tugas dan tanggung jawab masing-masing tanpa adanya curiga dalam rumah tangga akan menambah tentramnya rumah tangga, sehingga tujuan dari pada perkawinan dapat tercapai.

\section{B. Dampak terhadap anak}

Perceraian dipandang dari segi kepentingan anak yaitu keluarga bagi anak-anaknya merupakan tempat perlindungan yang aman dan nyaman, karena ada ibu dan bapak di keluarga tersebut, mendapat kasih sayang, perhatian, pengharapan, dan lain-lain yang cukup. Perlindungan hidup yang dirasa aman dan nyaman, pertumbuhan anak akan berkembang secara normal bahkan dapat lebih baik karena ada tempat untuk mengadu, tempat untuk meminta tentang segala apa yang diinginkan yang merupakan keperluan bagi anak-anak tersebut, baik berupa materil maupun moril nya. Apabila dalam suatu keluarga yang aman ini terjadi perceraian, anak-anak akan kehilangan tempat kehidupan yang aman dari hal itu dapat berakibat menghambat pertumbuhan hidupnya, baik secara langsung maupun tidak langsung.

Adapun akibat lain adanya kegoncangan jiwa, yang langsung dirasakan oleh anak-anaknya meskipun anak-anak ini dijamin kehidupannya dengan pelayanan yang baik oleh keluarga terpilih. Tetapi, kasih sayang ibu dan bapaknya sendiri akan berbeda dan gantinya tidak akan memberikan kepuasan yang sama kepadanya. Sebab betapa teguhnya kemantapan dan kesehatan jiwa yang diperoleh oleh si-anak jika belaian kasih sayang dari orang tuanya dirasakan langsung mulai dari bayi sampai meningkat menjadi anak-anak. Dengan melihat akibat perceraian yang kadangkadang langsung memperkosa hak anak itu, demi mendapatkan kasih sayang, maka perceraian merupakan sesuatu yang harus dihindarkan, kalau keadaan belum demikian mendorong.

Sebab itu semua dapat menimbulkan anak akan mencari perlindungan yang 
dirasa aman diluar perlindungan orang tuanya diluar rumah. Apabila yang demikian dapat terpenuhi, yaitu ia merasa senang dan aman berlindung di luar rumahnya, apalagi jika ia sudah meningkat sampai menilai bahwa perlindungan diluar rumahnya lebih baik. Sedangkan diluar rumah anak kerap kali bergaul dengan anak nakal, lama kelamaan akan terjalin rasa solider, sebab diantara mereka merasa senasib, meskipun hal-hal yang melatarbelakanginya berbeda. Hidup saling melihat dengan penuh perhatian satu sama lain, karena mereka akan merasa puas kalau mengganggu orang lain diluar lingkungannya. Misalnya mencuri kecil-kecilan, menggagu wanita di jalanan. Akibat bagi anak-anak dari keluarga yang pecah, dimana pergaulan di luar rumah tanpa mendapat pengawasan dari orang tuanya, akan mudah menimbulkan perilaku jahat.

Hal tersebut disebabkan karena:

$1 . \quad$ Anak kurang mendapatkan perhatian, kasih sayang dan tuntutan pendidikan dari orang tuanya, terutama bimbingan ayah, karena ayah dan ibunya sibuk mengurusi permasalahan serta konflik batin masingmasing.

2. Kebutuhan fisik maupun psikis anakanak menjadi tidak terpenuhi, keinginan harapan anak-anak tidak tersalur dengan semestinya, atau tidak mendapatkan kompensasinya.

3. Anak-anak tidak mendapatkan latihan fisik dan mental yang sangat diperlukan untuk hidup susilanya. Mereka tidak dibiasakan untuk disiplin dan mengontrol dirinya dengan baik.

Terjadinya pengabaian tersebut, anak-anak menjadi bingung, resah, risau, malu, sedih, sering diliputi perasaan dendam dan benci, sehingga pertumbuhan anak menjadi kacau dan liar. Dikemudian hari mereka mencari ganti rugi bagi kerisauan batin mereka sendiri di luar lingkungan keluarga, yaitu menjadi anggota dari suatu kelompok kriminal, lalu melakukan banyak perbuatan kriminal.

Pelanggaran kesetiaan loyalitas kepada patner hidup, pemutusan tali pernikahan, berantakanya kohesi dalam rumah tangga. Semua ini juga dapat memunculkan kecenderungan menjadi pelanggaran pada anak-anak dan remaja. Setiap perubahan dalam relasi personal antara suami-istri menjurus pada arah konflik dan perceraian. Maka perceraian merupakan faktor penentu bagi pemunculan kasuskasus neurotik, tingkah laku a-susila, dan kebiasaan delinkuen (Kartini Kartono, 2002).

Penolakan oleh kedua orang tuanya, jelas menimbulkan emosi, dendam, rasa tidak percaya karena merasa dikhianati, kemarahan dan kebencian, sentimen hebat itu memperlambat perkembangan hubungan manusiawi anak.

Muncullah kemudian ketidak harmonisan sosial dan lenyapnya kontrol diri, sehingga anak dapat dengan mudah digiring kearus yang buruk, lalu menjadi kriminal. Anak ini terlihat sadar, tetapi mengembangkan kesadaran yang tidak benar. Fakta memperlihatkan bahwa tingkah laku yang jahat tidak terbatas pada strata sosial bawah, dan strata ekonomi rendah saja, tetapi juga muncul pada semua kelas, khususnya dikalangan keluarga yang tidak harmonis.

Memang perceraian antara suami-istri dan perpisahan tidak selalu mengakibatkan kasus delinkuen dan karakter pada diri anak itu sendiri. Akan tetapi, semua bentuk ketegangan batin dan konflik biasanya mengakibatkan bentuk ketidakseimbangan kehidupan psikis anak. Selain itu juga tidak berkembangnya tokoh bapak sebagai sumber kekuasaan bagi anak laki-laki (Andry, Ostrovsky dan Naess, 1959). Sehingga anak berkembang menjadi 
kasar, liar, brutal, tidak terkendali, sangat agresif dan kriminal (Kartini Kartono, 2002).

Dari uraian tersebut diatas dapat disimpulkan bahwa antara kenyataan dengan teori sama yaitu sangat merugikan anak dan dapat mengganggu pertumbuhan anak.

Perceraian bagi anak merupakan tekanan batin yang sangat membahayakan jiwa anak. Karena setiap anak menginginkan orang tua yang utuh yaitu ada ibu dan bapak, mendapat kasih sayang dari mereka, perhatian, dan pengharapan.

Di tempat perlindungan anak yang dirasa aman pertumbuhan anak-anak akan berkenbang secara normal, karena ada tempat untuk mengadu, meminta segala apa yaang diinginkan yang merupakan keperluan bagi anak-anak itu, baik keperluan materiil maupun rohaniahnya. Untuk itu apabila terjadi perselisihan diantara mereka (orang tua anak) dapat diselesaikan dengan cepat dan jalan damai, jangan berlarut-larut, karena akan berdampak buruk bagi anak-anak.

Orang tua seharusnya dapat memahami betapa pentingnya pertumbuhan anak baik secara langsung maupun tidak langsung. Karena kasih sayang ibu sendiri atau bapak sendiri akan berbeda dan gantinya tidak akan memberikan kepuasan kepadanya.

\section{Dampak Terhadap Harta Kekayaan}

Apabila terjadi perceraian maka perikatan menjadi putus, dan kemudian dapat diadakan pembagian kekayaan perikatan tersebut. Jika ada perjanjian pernikahan pembagian ini harus dilakukan sesuai dengan perjanjian tersebut. Dalam suatu perceraian dapat berdampak terhadap harta kekayaan yaitu harta bawaan dan harta perolehan serta harta gono-gini atau harta bersama. Untuk harta bawaan dan harta perolehan tidak menimbulkan permasalahan, karena harta tersebut tetap dikuasai dan adalah hak masing-masing dari belah pihak.

Apabila terjadi penggabungan harta mereka karena perjanjian, maka penyelesaiannya juga harus disesuaikan dengan ketentuan perjanjian dan kepatutan. Harta milik bersama atau harta gono gini adalah harta yang dihasilkan dari suatu pernikahan baik dari pihak suami saja atau kedua-duanya harta yang diperoleh secara bersama-sama dalam suatu pernikahan.

Menurut pasal 35 UU No.1 tahun 1974 Juncto UU No 16 tahun 2019 tentang perubahan Undang-Undang Perkawinan harta perkawinan ada yang disebut harta bersama yakni harta benda yang diperoleh selama masa pernikahan. Di samping ini ada yang disebut harta bawaan dari masingmasing suami dan istri serta harta yang didapat dari masing-masing sebagai warisan sepanjang para pihak tidak menentukan.

Karena itu pasal 36 UUPerdata menentukan bahwa mengenai harta bersama, suami atau istri bisa bertindak atas persetujuan keduanya, sedang mengenai harta bawaan dan harta diperoleh masingmasing sebagai hadiah. Suami dan istri mempunyai hak sepenuhnya untuk melakukan perbuatan hukum mengenai harta bendan mereka. Menurut pasal 37 jo penjelasan pasal 35 UU No.1 tahun 1974 Juncto UU No 16 tahun 2019 tentang perubahan Undang-Undang Perkawinan, apabila perkawinan putus, maka harta bersama itu diatur menurut hukumnya masing-masing. Hal ini tidak dijelaskan pernikahan putus karena apa. Karena itu perkawinan putus mungkin karena salah satu pihak meninggal, mungkin pula karena perceraian.

Dengan demikian penyelesaian harta bersama adalah sebagai berikut:

1. Bagi mereka yang menikah menurut ketentuan agama Islam, hukum Islam tidak mengenal harta bersama, karena seorang 
isteri diberi nafkah oleh suami, yang ada ialah harta milik masing-masing suami dan isteri. Harta ini ialah hak mereka masingmasing.

2. Bagi mereka yang menikah menurut agama Islam dan agama-agama lainnya, tetapi tunduk kepada hukum adat yang mengenal harta bersama (harga gono-gini atau harta guna kaya), apabila terjadi perceraian bekas suami dan bekas istri masing-masing mendapat setengah (Yurisprudensi Mahkamah Agung No.387k/ Sip/ 1958 tanggal 11-2-1959 dan No. 392k/Sip/1969 tanggal 30-8- 1969).

3. Bagi mereka yang kawin menurut agama Kristen, tetap tunduk kepada BW yang mengenal harta bersama (persatuan harta sejak terjadi perkawinan). Jika terjadi perceraian, harta bersama dibagi dua antara bekas suami dan bekas istri, pasal 128 BW (Alumni Bandar Lampung: 1989).

Pasal 37 UU No.1 tahun 1974 Juncto UU No 16 tahun 2019 tentang perubahan Undang-Undang Perkawinan belum memberikan penyelesaian tuntas mengenai harta bersama dalam hal terjadi perceraian, palah masih menghidupkan dualisme hukum. Padahal hukum adat sudah memberikan penyelesaian yang adil yaitu separoh bagi bekas suami dan separoh bagi bekas istri.

Demikian juga BW memberikan penyelesaian bahwa harta bersama dibagi dua antara bekas suami dan bekas istri. Rumusan pasal 37 UUPerdata dibagi menjadi dua, setengah untuk bekas suami dan setengah untuk bekas isteri. Rumusan itu adalah sesuai dengan asas "hak dan kedudukan yang seimbang antara suami dan istri” . Akan tetapi, dalam hukum Islam harta Suami-Isteri terpisah masing- masing satu sama lainnya. Harta milik masing-masing pada waktu pernikahan dimulai, tetap menjadi miliknya sendiri-sendiri.

Demikian juga harta yang mereka peroleh masing-masing selama pernikahan tidak bercampur menjadi kekayaan bersama, tetapi tetap terpisah satu sama lain. Terhadap milik suami, si-isteri tidak berhak begitu saja, dan sebaliknya. Tetapi suamiisteri walaupun bukan sebagai pemiliknya tetap boleh memakai harta itu berdasarkan perjanjian antara suami-isteri yang biasanya berlaku secara diam-diam (Abdullah Kelib, 1990: 26).Dari uraian tersebut diatas, bahwa antara kenyataan dengan teori berbeda yaitu dalam kenyataan yang diperoleh dalam perkawinan merupakan merupakan harta bersama. Sedangkan secara teori (dalam Islam) walaupun harta diperoleh dalam perkawinan tetap saja milik masing-masing suami-isteri, kecuali ada perjanjian.

Pada hakekatnya pemeliharan anak dilakukan secara bersama oleh kedua ibu bapak, kecuali apabila terjadi perceraian diantara orang tuanya. Dalam hal ini seorang ibulah yang berkuasa merawat anak sampai anak itu mencapai tingkat "mumayiz", mumayiz artinya sudah dapat membedakan antara yang baik dan yang buruk. Kemudian setelah masa ini anak dapat memilih sendiri kepada siapa dia akan bertempat tinggal atau di asuh.

Apabila pengasuhan ibunya akan mendatangkan kemaslahatan bagi anak maka ia harus ikut kepada ibunya. Jika ibu sudah meninggal maka untuk mengganti status ibu, diserahkan pengasuhan anak kepada neneknya. Baru kemudian apabila para leluhur dari garis ibu sudah tidak ada, bapaknya berkuasa melakukan "aiddhonah ” yaitu memelihara person si-anak yang belum dewasa yang meliputi pemeliharaan jasmaniah, pemberian tempat tinggal, pemeliharan pendidikan, penghayatan agama, memberikan kasih sayang, simpati, pengertian, dan perhatian pada anak-anak yang cukup. Jika ayahnya sudah meninggal juga maka aidhonah dapat dilakukan oleh ibu dari ayah terus keatas. Jika mereka sudah tidak ada lagi maka aidhonah dilakukan oleh sanak saudara yang terdekat hubungan kekeluargaan dengan si-anak.

Sedangkan kekuasaan wilayat al-mal 
yaitu memelihara kekayaan si-anak dan kepentingan-kepentingannya yang berhubungan dengan harta kekayaan, dilakukan oleh si-ayah. Jika ayah meninggal dunia maka kekuasaan itu di ganti oleh ayahnya terus keatas. Kekuasaan wilayat almal akan berlangsung sampai si-anak mencapai tingkatan "rasyid" artinya telah mampu untuk mengurus sendiri kekayaannya. Untuk mengetahui apakah anak sudah cerdas atau belum biasanya dilakukan dengan penyerahan atas sejumlah tertentu dari hartanya kekayaanya sebagai percobaan. Dalam masa percobaan ini dapat diketahui apakah anak itu sudah mampu menggunakan hartanya dalam arti efektif dan disertai pertanggung jawaban atau belum. Jika sudah mampu, maka harta kekayaan diberikan sepenuhnya kepada anak tersebut. Apabila belum mampu, hingga uang tersebut digunakan untuk halhal yang tidak ada manfaatnya atau dihambur-hamburkan saja secara tidak bertanggung jawab, maka kekuasaan wilayat harta kekayaan tetap dipegang oleh wakilnya.

Menurut hukum Islam apabila bercerai dua orang suami-isteri, sedang keduanya sudah mempunyai anak yang belum mumayiz (belum mengerti kemaslahatan dirinya), maka isterilah yang berhak untuk mendidik dan merawat anaknya itu, sehingga sampai ia mengerti akan kemaslahatan dirinya sendiri. Pada saat itu hendaklah si-anak tinggal bersama ibunya, selama ibunya belum menikah dengan orang lain. Meskipun si-anak ditinggalkan bersama ibunya, tetapi belanjanya tetap wajib dipikul oleh bapaknya. Apabila si-anak sudah mengerti, hendaklah diselidiki oleh yang berwajib, siapakah diantara keduanya (ibu atau bapak) yang lebih baik dan lebih pandai, untuk mendidik anak itu, maka hendaklah si-anak diserahkan kepada yang lebih cakap untuk mengatur kemaslahatan anak tersebut. Akan tetapi, kalau keduanya sama saja, anak itu harus disuruh memilih kepada siapa diantara keduanya dia lebih suka.

Dari uraian diatas, dapat disimpulkan bahwa antara kenyataan dan teori sama yaitu ibu yang berhak mendidik dan merawat anaknya, dan apabila anak telah sedikit mengerti maka anak dapat memilih dengan siapa dia akan tinggal. Harta kekayaan merupakan hal yang sangat riskan untuk membaginya. Karena keadilan dalam pembagian harta kekayaan sulit didapatkan. Oleh sebab itu Pengadilan atau pihak yang berwenang dapat melakukan pembagian harta kekayaan sesuai kesepakatan masingmasing, dan tidak merugikan satu sama lain atau saling menguntungkan diantara keduanya. Hingga tidak menimbulkan perpecahan diantara keluarga pasangan suami- isteri tersebut. Dengan maksud walaupun mereka sudah resmi bercerai, tetapi mereka masih menjalin hubungan kekeluargaan yang baik.

\section{PENUTUP}

\section{Kesimpulan dan Rekomendasi}

\section{Kesimpulan}

Dari hasil penelitian dan pembahasan yang dilakukan, peneliti dapat menarik kesimpulan, bahwa faktor-faktor penyebab perceraian, proses persidangan dan dampak yang dilakukan di wilayah Pengadilan Agama Palembang adalah sebagai berikut: Faktor-faktor Penyebab Perceraian moral merupakan tingkah laku, perbuatan, percakapan, bahkan sesuatu apapun yang berpautan dengan norma-norma kesopanan, yang harus/ dilindungi oleh hukum demi terwujudnya tata tertib dan tata susila dalam kehidupan bermasyarakat contohnya Poligami yang salah merupakan poligami yang dilakukan karena tidak memenuhi alasan dan syarat poligami itu sendiri sesuai dengan pasal 4 dan 5 Undang-Undang Nomor.1 tahun 1974 Juncto UU No 16 tahun 2019 tentang perubahan Undang-Undang Perkawinan. Krisis akhlak sama dengan perselingkuhan yaitu melakukan hubungan sek dengan orang lain 
yang bukan isteri atau suaminya tanpa diketahui masing-masing atau diketahui setelah melakukan hubungan seks oleh salah satu pihak atau keduanya atau orang lain.

a. Meninggalkan kewajiban yaitu kewajiban yang ditinggalkan oleh suami atau isteri baik berupa nafkah lahir maupun batin.

1. Kawin paksa merupakan perkawinan yang dipaksakan oleh keluarga yaitu orang tua, saudara dari suami atau isteri atau yang lainnya. Hal ini dapat menyebabkan perselisihan karena tidak adanya rasa cinta (suka sama suka) diantara mereka.

2. Ekonomi terjadi karena kurang tercukupinya kebutuhan ekonomi dalam rumah tangga, karena keinginan yang berlebihan, sedangkan pendapatan lebih kecil dari pada pengeluaran. Hal ini dapat menyebabkan perselisihan dan dapat berakhir dengan perceraian.

3. Kawin di bawah umur merupakan perkawinan yang dilakukan karena belum cukup umur yaitu laki-laki kurang 19 tahun dan wanita kurang 19 tahun menurut UU No.1 tahun 1974 Juncto UU No 16 tahun 2019 tentang perubahan Undang-Undang Perkawinan. Pernikahan ini banyak yang tidak harmonis karena mereka belum memahami dengan benar arti dan tujuan dari perkawinan itu sendiri, sehingga apabila terjadi kegoncangan dalam rumah tangga mereka belum dapat mengatasinya.

4. Penganiayaan merupakan perlakuan kejam yang dilakukan oleh suami terhadap isteri atau sebaliknya oleh isteri terhadap suami, baik berupa jasmani maupun rohani. Contoh: memukul isterinya dan sebagainya.

5. Terus menerus berselisih disebabkan karena adanya cekcok terus-menerus, sehingga dengan upaya apapun tidak dapat didamaikan.
6. Gangguan pihak ketiga yaitu adanya campur tangan yang dilakukan oleh pihak ketiga dapat berasal dari keluarga (orang tua, saudara dari suami atau isteri atau teman dekat atau yang lainnya) yang meyebabkan perbedaan prinsip/ salah paham antara suami dan isteri, hingga terjadi perseteruan yang hebat dan upaya damai sudah tidak bisa lagi sehingga berakhir dengan cerai.

7. Tidak ada keharmonisan dikarenakan adanya cekcok terus menerus. Untuk menentukan ada atau tidaknya cekcok maka salah satu pihak (suami/ isteri), harus dapat membuktikan kepada Pengadilan tentang hal yang menyebabkan cekcok dalam rumah tangga, karena terjadi konflik terus dan tidak ada jalan keluar kecuali dengan perceraian.

\section{Rekomendasi.}

a. Untuk menhadakan suatu pernikahan diharapkan mempunyai persiapan yang benar-benar siap, untuk mengurangi angka perceraian.

b. Bagi kedua orang tua hendaknya tidak memaksakan anaknya untuk menikah dengan orang yang tidak dicintainya, karena apabila diteruskan dapat berakibat buruk bagi pernikahan mereka.

c. Hendaknya dilakukan penyuluhan kepada masyarakat yang menyangkut hukum pernikahan dan perceraian dengan segala aspeknya, guna merangsang kekokohan ikatan pernikahan dan menguraangi angka perceraian.

d. Dalam persidangan hendaklah para hakim berlaku adil terhadap semua orang yang ingin bercerai, hingga lembaga penegak hukum dan para petugasnya dapat dipercaya oleh masyarakat.

e. Perceraian disarankan sebagai upaya terakhir apabila perdamaian dalam rumah tangga tidak dapat diraih, karena hal ini sangat dibenci Allah SWT 


\section{DAFTAR PUSTAKA}

Achmad, Djumairi. S.H. 1990. Hukum Perdata II. Semarang: Dosen Fakultas Syari' ah IAIN Walisongo

Arikunto, Suharsimi. Prof.Dr. 1998. Prosedur Penelitian. Yogyakarta: Rineka Cipta

Ashofa, Burhan. S.H. 1998. Metode Penelitian Hukum. Jakarta: PT.Rineka Cipta.

Kartini, Kartono. Dr. 2002. Patologi Sosial 2 Kenakalan Remaja. Jakarta: Grafindo Persada.

Makmur. S.H., Subekti. Hermien. S.H. 1991. Metode Penelitian Hukum. Ungaran: Badan Penyediaan diktat kuliah FH UNDARIS.

Miles, 1992 Milles, Mattehew.B. Hubermen, Michael.A. 1992. Analisis Data Kualitatif. Jakarta: Universitas Indonesia.

Moleong, Lexy J. Dr.M.A. 2000 Metodologi Penelitian Kualitatif. Bandung: PT.Remaja Rosdakarya

Subekti, Prof.S.H. Tjitrosudibio R. 1995. Kitab Undang-Undang Hukum Perdata, Jakarta: PT.Pradya Paramita.

Soemin, Soedaryono. S.H. 1992. Hukum Orang dan Keluarga. Jakarta: Sinar Grafika.

Undang-Undang perkawinan no 1 tahun 1974 juncto Undang-Undang Nomor 16 tahun 2019 Tentang Perubahan Undang-Undang No.1 Tahun 1974

Permatasari, E. Diambil kembali dari, https://www.hukumonline.com/klinik/detail/ulasan/cl5021/cara-mengurus-perceraiantanpa-advokat/ diakses bulan April 2021.

PP No. 9 tahun 1975 tentang pelaksanaan Undang-Undang No.1 TTahun 1974

Wilianto, A. Diambil kembali dari https://www.kompas.com/skola/read/2020/07/07/123000469/manusiasebagai-makhluk-sosial-dan-cirinya?page=all di akses bulan April 2021.

Yurisprudensi Mahkamah Agung No.387k/ Sip/ 1958 tanggal 11-2-1959 dan No.392k/ Sip/ 1969 